\title{
Practice of Self Assessment by Undergraduate Dental Students In Academic Study
}

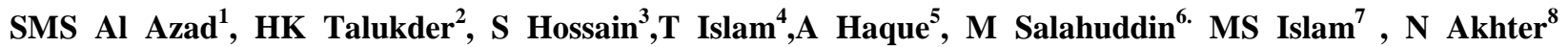

\begin{abstract}
This descriptive type of cross sectional study was carried out with the objective of exploring the views of undergraduate dental students about practice of self assessment practice in their academic study at Government \& non Government dental colleges in 2009. $1^{\text {st }} \& 2^{\text {nd }}$ year dental students were the study population here. Sample size was 262.Data was collected by self administered semi structured questionnaire adapting purposive sampling. Study revealed that most of the respondents suggested practice of self assessment is necessary for academic development. The reason behind their practicing of self assessment were stated as because self assessment build self confidence \& knowledge, identify gaps \& laps of study, improve thyself for better academic performance, helps to build a good professional career \& fulfil the aims \& goals of life. Regarding the process of self assessment major portion of the respondents followed teachers suggestion \& advices of their guardian as their means of self assessment most of the times. Group study, peer feedback, solving previous question, senior students advices \& note khatas were used as self assessment tool. In this study it was also found that barriers regarding self assessment were excessive work load in most of the cases 164(70\%). On the other hand, self assessment practice was also hampered by lack of facility for group study, non cooperative tendency of the students, lack of feedback from the teachers $\&$ frequent examination. Most of the times self assessment practice, factors affecting self assessment \& also the barriers regarding self assessment are somehow related to their teachers, guardian \& academic examination with the results. So if self assessment practice is being made a provision institutionally it will be beneficial for undergraduate dental students \& the institutes. For this it should be ensured that there is proper institutional set up, exact organization, required resources (Faculty, technical support, stuff cooperation) \& perfect coordination both intra \& inter institutionally all over the country controlled by a central authority. For more information \& exact concept as well as proper implementation more \& more study can be done regarding self assessment in a wider scale taking all the events of self assessment into consideration.
\end{abstract}

\author{
${ }^{1}$ Asst. Professor, Department of SDM, Mandy Dental \\ College, \\ ${ }^{2}$ Associate Professor, Teaching Methodology\& coordinator, \\ CME. \\ ${ }^{3}$ Professor Of Neuro-Medicine, \\ ${ }^{4}$ Lecturer, State College Of Health Sciences. \\ ${ }^{5}$ Lecturer, Dental Pharmacology. \\ ${ }^{6}$ Assistant Professor, ENT, ${ }^{7}$ Asst. Prof (Skin \&VD) CME, \\ ${ }^{8}$ Assistant Professor, (Gynae \& Obs) SSMC.
}

\section{Introduction}

Assessment is the process of testing a student's ability. An assessment is not only a measure of performance but also provides an indication of the effectiveness of teaching situation and also the appropriateness of content input. Assessment is done to quantify students marks for the purpose of certification or grading, to measure and improve the effectiveness of the course, by giving feedback to the students and teachers by analyzing students answer to give some insight into the process or instruction. As 'with conventional assessment, the judgments can range from 'pass-fail' (or pass - not-yet-pass) decisions, to percentage marks or grades $\mathrm{A}$ to $\mathrm{E}$, and so on. The assessment decisions can be made by students on their own essays, reports, presentations, performances, projects, dissertations, and even exam scripts. However, student self-assessment can be even more valuable when the evidence to be assessed is intrinsically personal in nature, such as reflective logs, diaries, action plans, and so on ${ }^{13}$

Address of Correspondence: Dr. S.M. Salahuddin Al Azad, Assistant Professor, Science Of Dental Materials, Mandy Dental College.

where it can be argued that only the student really knows how well the evidence meets the purposes or criteria designed to specify it.

Self-assessment cannot of course be anonymous, and where self-assessment is part of an overall assessment profile this means that assessment decisions are made in a more 'exposed' setting than where anonymous peer-assessment is used. Selfassessment can be influenced by the tendency to make judgments on what was meant rather than what was actually achieved. Self Assessment Can be an effective tools in developing an awareness of one`s 
own working method \& encouraging objective self examination. A little time spent objectively evaluating one's own work is likely to improve sense of satisfaction \& will help to upgrade the overall quality .Thus the success of the higher education as well as university education. When self-assessments are done without linkage to one another learners may not benefit as much as when that linkage is part of a more holistic approach to learner self-assessment. Self assessment allows for contemplation and integration to occur because students are asked to make sense not only of particular self-assessment tools, but of the total package of tools they complete. Further, and in a more general sense, we believe that systematic, integrative self-assessment have merit for increasing learner's abilities and motivations to 'Know Thyself'.Traditional assessment is sometimes regarded as an exercise of power by the assessor/examiner over the assessee. In selfassessment the role of the lecturer or trainer can change to that of external examiner and moderator. If we see education as fostering achievement in a personal sense [then] an emphasis on personal achievement, focussing on self-knowledge, selfassessment, and self-regulation appears long overdue. In Undergraduate dental education i.e. B.D.S course normally self assessment is done by the students according to their own strategy without having any proper guideline. Choice of technique \& method along with the process of self assessment depends on the psychology, personality \& attitude to future education. But it is definite that students don't follow any individual strategy $\&$ most of the students never follow any self assessment. Some portion of the students assess their self learning by writing to justify the recall capacity \& some students adopt peer discussions while other prefers learning diaries regularly. Before this study there was not adequate \& organized study over this aspect.

In most of the cases student fails to evaluate themselves due to lack of provision of self assessment as a regular phenomenon both individually or institutionally. So instead of being profound infrastructural framework day by day there is incidence of decreasing the level of understanding \& application of knowledge gained in undergraduate dental study. Respectively when the students are going to be trained or educated furthermore fall of basic quality most of the time observed by the expertise . Ultimately there is creation of unexpected system loss in case of medical as well as dental study in comparison with the global standard. If self assessment can be practiced institutionally by the faculty $\&$ the authority it will be supported by the guardians probably. So students will be always be in a circle of self evaluation \& justification of his own along with the associated factors particularly in academic study.

\section{Medical colleagues}

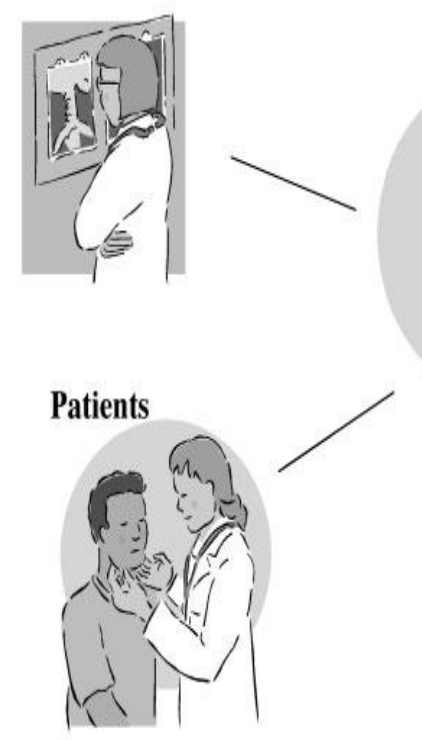

Self-assessment

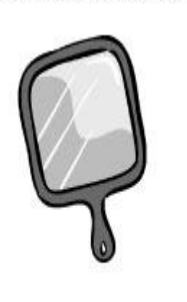

Coworkers

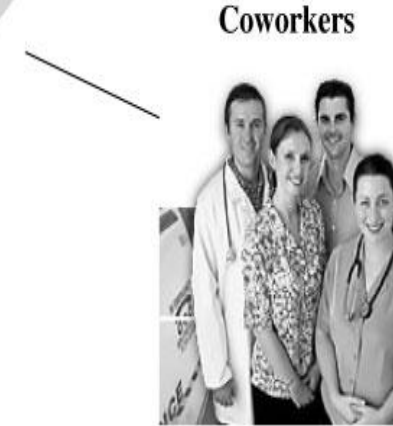

\section{Methodology}

Descriptive Cross sectional study was adopted. It included both quantitative \& qualitative data. Study period was from July 2009 to June 2010

Dhaka Dental College, City Dental College, Rangpur Dental College \& Pioneer Dental College were the study place. $1^{\text {st }} \& 2^{\text {nd }}$ year Students of Selected Dental College. Students of 1st \& 2nd year were involved in this study as self assessment varies in clinical year i.e Phase-II. So we want to get information from the students of basic science. Sample sizes were 262 .Self administered Semi structured Written Questionnaire were used as data collection tool. Permission from the respective Dental college authorities (Principles) was formally sought beforehand. Data were collected from 1 Govt. \& 3 non Govt. Dental colleges through self administered semi structured questionnaire. 262 students filled up the questionnaire. Information was collected through focus group discussion among the students of 1 govt. \& 1 private Dental college.

Collected data were edited \& coded manually \& then entered in statistical program SPSS version for analysis. Data were expressed in both in quantitative $\&$ qualitative form. 


\section{Result}

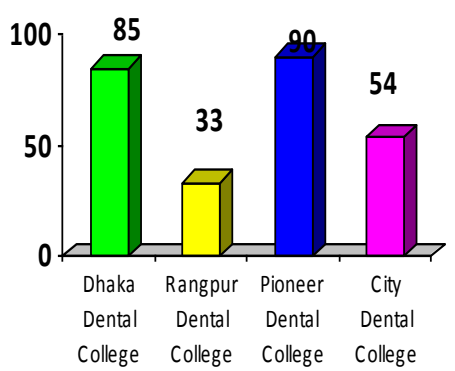

Graph 1 : Shows that out of four Dental College 85(20.6\%) were from Dhaka Dental College, 33 (13\%) from Rangpur Dental College , \& 90(34\%) from Pioneer Dental College \& 54 (21\%) from City Dental College

Chart 1 : Distribution of the respondents by gender

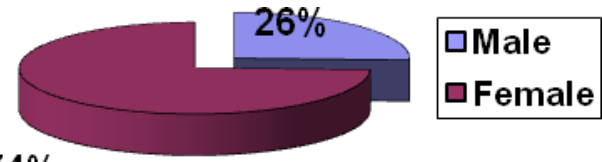

$74 \%$
Chart 1 has shown that out of 262 respondents 67 ( $26 \%$ ) of the were male \& $195(74 \%$ ) were female.

Chart 2 : Distribution of the respondents by Academic year

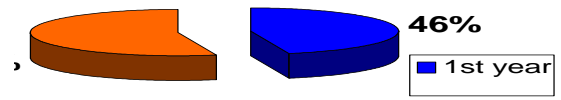

Chart-2 Shows that among the respondents of all the Dental College Of the Study out of 262 respondents $120(45.8 \%)$ were Students Of $1^{\text {st }}$ year \&142( 54.2\%) were the students of $2^{\text {nd }}$ year.

In this study out of 262 respondents $25.6 \%$ of the respondents were male \& $74.4 \%$ were female. Among all the respondents $33(12.6 \%)$ were from Dhaka Dental College, 85(20.6\%) from City Dental College, 90(32.4\%) from Rangpur Dental College \& 54( 34.4\%) from Pioneer Dental College. Among the respondents of all the Dental College of 262 respondents $120(45.8 \%)$ were Students Of $1^{\text {st }}$ year $\& 142(54.2 \%)$ were the students of $2^{\text {nd }}$ year.

Table 1 : Distribution of the respondents as per their views regarding the ways $\&$ means of their self assessment $\mathrm{n}=\mathbf{2 6 2}$

\begin{tabular}{|l|c|c|c|c|c|}
\hline \multicolumn{1}{|c|}{$\begin{array}{c}\text { Ways \& means of self } \\
\text { assessment practiced by } \\
\text { the respondents }\end{array}$} & \multicolumn{5}{|c|}{ Different level of self assessment practice by the students } \\
\cline { 2 - 6 } & Always & Most of the time & Some times & Rarely & Never \\
\hline $\begin{array}{l}\text { Result of previous } \\
\text { examination }\end{array}$ & $90(36.3)$ & $126(50.8)$ & $31(12.5)$ & $1(.4)$ & - \\
\hline Note Khatas & $123(47.9)$ & $78(30.4)$ & $33(12.8)$ & $17(6.6)$ & $6(2.3)$ \\
\hline Solving Previous questions & $107(42.1)$ & $77(30.3)$ & $57(22.4)$ & $9(3.5)$ & $4(1.6)$ \\
\hline Group Study & $65(25.4)$ & $78(30.5)$ & $76(29.7)$ & $25(9.8)$ & $12(4.7)$ \\
\hline Peer Feedback & $53(22.1)$ & $91(37.9)$ & $70(29.2)$ & $19(7.9)$ & $7(2.9)$ \\
\hline Teacher's suggestions & $180(70.0)$ & $60(23.3)$ & $16(6.2)$ & $1(.4)$ & - \\
\hline Parents' advices & $165(64.0)$ & $56(21.7)$ & $27(10.5)$ & $8(3.1)$ & $2(.8)$ \\
\hline Senior Student's advices & $50(19.8)$ & $65(25.8)$ & $85(32.4)$ & $38(15.1)$ & $14(5.6)$ \\
\hline
\end{tabular}


Table 2 : Distribution of the respondents as per their views about positive factors affecting their self assessment practice. $\quad \mathrm{n}=262$

\begin{tabular}{|l|c|c|c|c|c|}
\hline \multirow{2}{*}{$\begin{array}{c}\text { Positive factors affecting } \\
\text { self assessment practice }\end{array}$} & \multicolumn{5}{|c|}{ Different level of self assessment practice } \\
\cline { 2 - 6 } & Always & Most of the time & Some times & Rarely & Never \\
\hline Academic performances & $120(47.2)$ & $91(35.8)$ & $34(13.0)$ & $5(2.0)$ & $4(1.6)$ \\
\hline Career plan & $163(63.7)$ & $66(25.8)$ & $19(7.4)$ & $6(2.3)$ & $2(.8)$ \\
\hline Advices of teacher & $154(59.9)$ & $80(31.1)$ & $19(7.4)$ & $2(.8)$ & $2(.8)$ \\
\hline Advices of guardian & $155(60.1)$ & $70(27.1)$ & $23(8.9)$ & $7(2.7)$ & $3(1.2)$ \\
\hline Advices of Peer & $43(16.9)$ & $103(39.3)$ & $81(31.8)$ & $20(7.8)$ & $8(3.1)$ \\
\hline Advices of senior students & $32(12.6)$ & $71(28.0)$ & $94(37.0)$ & $43(16.9)$ & $14(5.5)$ \\
\hline Competition with others & $91(35.8)$ & $63(24.8)$ & $53(20.9)$ & $24(9.4)$ & $23(9.1)$ \\
\hline
\end{tabular}

Table 3 : Distribution of the respondents according to their views regarding areas in which self assessment help their academic study $. \mathrm{n}=262$

\begin{tabular}{|l|c|c|c|c|c|}
\hline \multirow{2}{*}{$\begin{array}{l}\text { Areas in which self assessment } \\
\text { help the respondents in their } \\
\text { academic study }\end{array}$} & \multicolumn{4}{|c|}{ Different level of self assessment practice } \\
\cline { 2 - 5 } & Always & $\begin{array}{c}\text { Most of the } \\
\text { time }\end{array}$ & Some times & Rarely & Never \\
\hline $\begin{array}{l}\text { Identify weakness \& learning } \\
\text { gaps }\end{array}$ & $150(58.1)$ & $81(31.4)$ & $24(9.3)$ & $3(1.2)$ & - \\
\hline Learn better & $147(57.6)$ & $89(34.9)$ & $19(7.5)$ & - & - \\
\hline $\begin{array}{l}\text { Perform better in future } \\
\text { examination }\end{array}$ & $157(61.1)$ & $87(33.9)$ & $11(4.3)$ & $2(.8)$ & - \\
\hline Increase self confidence & $151(59.0)$ & $83(32.4)$ & $20(7.8)$ & $2(.8)$ & - \\
\hline $\begin{array}{l}\text { Create good relationship with } \\
\text { peer }\end{array}$ & $119(47.2)$ & $94(37.3)$ & $29(11.5)$ & $5(2.0)$ & $5(2.0)$ \\
\hline $\begin{array}{l}\text { Create good relationship with } \\
\text { seniors }\end{array}$ & $81(31.5)$ & $85(33.1)$ & $54(21.0)$ & $30(11.7)$ & $7(2.7)$ \\
\hline $\begin{array}{l}\text { Create good relationship with } \\
\text { teachers }\end{array}$ & $161(62.6)$ & $72(28.0)$ & $17(6.6)$ & $6(2.3)$ & $1(.4)$ \\
\hline Find out new areas of enquiry & $65(26.4)$ & $77(31.3)$ & $79(32.1)$ & $20(8.1)$ & $5(2.0)$ \\
\hline
\end{tabular}


Table 04: Distribution of the respondents regarding the importance of Self assessment to them

\begin{tabular}{|l|c|c|}
\hline $\begin{array}{c}\text { Different level of importance } \\
\text { of self assessment }\end{array}$ & Frequency & Percent \\
\hline Very important & 167 & 76.6 \\
\hline Important & 40 & 18.3 \\
\hline Some important & 2 & .9 \\
\hline Minimum important & 3 & $1.4 \%$ \\
\hline Very minimum important & 6 & 2.8 \\
\hline Total & 262 & 100.0 \\
\hline
\end{tabular}

Table 05 : Distribution of the respondents by their views regarding barriers for self assessment. $\mathrm{n}=\mathbf{2 6 2}$

\begin{tabular}{|l|c|c|}
\hline $\begin{array}{c}\text { Barriers of self assessment } \\
\text { according to views of } \\
\text { respondents }\end{array}$ & Frequency & Percentage \\
\hline Excessive work load & 164 & 73.5 \\
\hline $\begin{array}{l}\text { Frequent academic } \\
\text { examination }\end{array}$ & 56 & 25.1 \\
\hline $\begin{array}{l}\text { Lack of feedback from the } \\
\text { teachers }\end{array}$ & 65 & 29.1 \\
\hline $\begin{array}{l}\text { non cooperative tendency of } \\
\text { the students }\end{array}$ & 101 & 45.3 \\
\hline $\begin{array}{l}\text { Lack of facility for group } \\
\text { study }\end{array}$ & 111 & 49.8 \\
\hline $\begin{array}{l}\text { Absence of proper } \\
\text { educational environment }\end{array}$ & 105 & 47.1 \\
\hline Others & 2 & 0.9 \\
\hline
\end{tabular}

Table 06 : Distribution of respondents by their views whether self assessment practice is necessary for their academic development or not $\mathbf{n}=\mathbf{2 5 0}$

\begin{tabular}{|l|c|c|}
\hline $\begin{array}{c}\text { Respondents groups } \\
\text { who viewed }\end{array}$ & Frequency & Percent \\
\hline $\begin{array}{l}\text { 'Yes' self } \\
\text { assessment practice } \\
\text { is necessary }\end{array}$ & 240 & 96 \\
\hline $\begin{array}{l}\text { 'No' self assessment } \\
\text { practice is not } \\
\text { necessary }\end{array}$ & 10 & 4 \\
\hline Total & 250 & 100 \\
\hline
\end{tabular}

Table 07 : Distribution of respondents by their views who think self assessment practice is necessary for their academic development $. n=250$

\begin{tabular}{|l|c|c|}
\hline \multicolumn{1}{|c|}{ Views } & Frequency & Percent \\
\hline $\begin{array}{l}\text { Build self confidence } \\
\text { \& knowledge }\end{array}$ & 92 & 36.8 \\
\hline $\begin{array}{l}\text { Identify gaps \& laps } \\
\text { of study }\end{array}$ & 51 & 20.4 \\
\hline $\begin{array}{l}\text { Improve thyself for } \\
\text { better academic } \\
\text { performance }\end{array}$ & 34 & 13.6 \\
\hline $\begin{array}{l}\text { Building a good } \\
\text { professional carrier }\end{array}$ & 21 & 8.4 \\
\hline $\begin{array}{l}\text { Self judgment \& } \\
\text { evaluation }\end{array}$ & 33 & 7.6 \\
\hline $\begin{array}{l}\text { Fulfillment of aims } \\
\text { and goal of life }\end{array}$ & 19 & \\
\hline
\end{tabular}


Table 08: Distribution of the respondents as per students view who think self assessment practice is not necessary for academic development . $n=10$

\begin{tabular}{|l|c|c|}
\hline $\begin{array}{c}\text { Views of the } \\
\text { respondents }\end{array}$ & Frequency & Percent \\
\hline No time for study & 03 & 30 \\
\hline $\begin{array}{l}\text { Emotional state } \\
\text { confuse }\end{array}$ & 02 & 20 \\
\hline $\begin{array}{l}\text { No creativity in } \\
\text { medical science }\end{array}$ & 03 & 30 \\
\hline Frequent exam & 02 & 20 \\
\hline Total & 10 & 100.0 \\
\hline
\end{tabular}

\section{Discussion}

This cross sectional study was carried out among the $1^{\text {st }} \& 2^{\text {nd }}$ year students of one Government \& 3 non Government dental colleges. From these students information were collected on the practice of self assessment by undergraduate dental students in their academic study. Students of clinical year that is $3^{\text {rd }}$ year $\& 4^{\text {th }}$ year were not included in this study because they are busy with clinical work as well as theoretical or lecture class. Besides clinical teaching is different part which is again related to clinical clerkship. Information were collected through a semi structured self administered questionnaire from 262 students of both $1^{\text {st }} \& 2^{\text {nd }}$ year from one government $\&$ three non government dental colleges. The questionnaire included different aspects of self assessment practice regarding the process of self assessment, factors affecting self assessment, barriers of self assessment to be rated using Likert scale provided. Open ended questions were also included in the questionnaire to collect qualitative information from the respondents about the practice of self assessment.

In this study out of 262 respondents $25.6 \%$ of the respondents were male \& $74.4 \%$ were female. Among all the respondents $33(12.6 \%)$ were from Dhaka Dental College, 85(20.6\%) from City Dental College, 90(32.4\%) from Rangpur Dental College \& 54( 34.4\%) from Pioneer Dental College. Among the respondents of all the Dental College of 262 respondents $120(45.8 \%)$ were Students Of $1^{\text {st }}$ year $\& 142(54.2 \%)$ were the students of $2^{\text {nd }}$ year.
According to the table we can get a clear idea that in the perspective of our undergraduate dental students most of them assessed themselves whether according to their parents` advices or their teachers suggestions. It was done always according to their views even who does not assess themselves always, they followed same strategy most of the time or sometimes. Next to it group study, solving previous question, peer feedback \& result of previous examination was practiced as means of self assessment in their academic study. There was no strong comments about rare practice of self assessment. That's why it is presumed that students assess themselves somehow. If we again analyze the finding according to their academic year it is observed that both of the students of $1^{\text {st }} \& 2^{\text {nd }}$ year students followed teachers suggestion \& parents advices as the process of self assessment always or most of the times. Occasionally or sometimes they practiced group study, peer feedback \& solving previous question of the examination.

According to the table it is also observed that Out of 262 respondents as per the student's views $167(77 \%)$ thought it as very important for academic study, $40(18 \%)$ as important for academic study. Some sort of importance was thought by $2(.9 \%)$, minimum important was thought by $3(1.4 \%)$ \& very minimum important was thought by $6(2.8 \%)$ respondents about self assessment as per their views.

According to the analysis it can be stated that of respondents out of 262 respondents 164 (73.5\%) thought excessive workload as barrier for self assessment while 56(25.1\%) thought frequent academic examination as their barrier \& 65(29.1\%) thought lack of feedback from the teacher as barrier for self assessment. Self assessment can be hampered as like barriers by non cooperative tendency of the students according to $101(45.3 \%)$, by lack of facility for group study according to $111(49.8 \%)$, by absence of proper educational environment according to $105(47.1 \%) \&$ by others according to $2(.9 \%)$ respondents.

There are several other reasons for inaccuracy in self assessment as misapprehension where students do not understand what is expected of them, self-deception in which most medical students are people who have performed well at school and have received strong positive feedback from a young age, giving them a self confidence that may be resistant to modification \& scoring of potential or ideal (rather than actual) performance \& scoring of effort rather than achievement whereas bright primary school children overestimate their abilities, the reverse (as we have 
found) is true in higher education. Brown ${ }^{6}$ suggest that this shift is associated with the development of self and self-presentation; we learn to distinguish between assessing oneself for oneself and assessing oneself for others \& Compensation for poor performance as a defense mechanism ${ }^{8}$. Regarding the necessity of self assessment in academic study according to the students' views majority of the respondents $240(96 \%)$ expressed that self assessment practice is necessary for academic development. Out of 250 respondents only $10(4 \%)$ viewed that self assessment practice is not necessary for academic development

Result also shows that among the respondents who think self assessment practice is necessary- 92(39\%) expressed that self assessment build self confidence \& knowledge, 51(20\%) expressed that self assessment identify gaps \& laps of the study. Similarly according to $34(14 \%)$ respondents self assessment is necessary to improve thyself for better academic performance ,21(8\%) respondents self assessment is essential to build a good professional carrier, 33(13\%) respondents self assessment is required to judge \& evaluate thyself \& 19(8\%) respondents self assessment is necessary for fulfillment of aims \& goal of life.

Among the respondents who thought self assessment practice is not necessary out of $1030 \%(03)$ viewed that self assessment practice is not necessary in academic development because of less time. According to $20 \%$ (02) respondents` observation emotional state confuse them to practice self assessment in academic study , 30\%(03) respondents observation as there is no creativity in medical science, self assessment is not necessary to practice \& 20\% (02) respondents view frequent examination is responsible for not practicing self assessment in academic study.

\section{Conclusion}

Traditional assessment only certifies \& accredates the achieved knowledge not the perchieved one. Though in the form of formative assessment some parts of self assessment is done in our traditional or existing curriculum as well as assessment system, it does`nt fill the criteria of exact self assessment protocol. In the perspective of our country self assessment is practiced by the students as well as the teachers also but it has no recognition or exposure due to not practicing it institutionally. In case of global perspective most of the Medical institutes or Controlling authority emphasize on the portfolio approach as their self assessment protocol \& also for the continuing professional development. We have no such type of system in our country both in undergraduate \& postgraduate medical as well as dental institutes whether government or non government. But we have some system or strategy like logbook supervised by the expert or departmental seniors in case of clinical evaluation \& assessment not for the academic study. The suggestion \& comments in this study as put forward by the undergraduate dental students regarding the process of self assessment, factors affecting the self assessment practice, importance of this practice of self assessment \& barriers for self assessment includes the following-

i. Students adopt advices of the their parents \& suggestions of their teacher as the means of self assessment in majority of the occasion \& they practice it always .

ii. Result of previous examination, group study \& peer feedback is considered as supportive \& associate means for self assessment to them,

iii. Factors like carrier planning, advices of the guardian \& advices of teacher positively affect the self assessment always or most of the time.

iv. Academic performances, competition with the others \& advices of peers \& seniors contribute list as affecting factors for self assessment practice occasionally.

v. In majority of the cases self assessment helps to identify the learning gaps \& weakness of study, increase self confidence, aids in performing better in the academic examination, create good relationship with the teachers.

vi. Occasionally self assessment helps to create good relationship with the peers $\&$ seniors as well as aids in finding the new areas of enquiry.

vii. In most of the occasion excessive workload during \& after the class, frequent academic examination as well as the lack of feedback from the teachers \& non cooperative tendency of the students \& proper educational environment hampers their self assessment practice. 


\section{References}

Self Assessment in medical Practice ; AW Evans, C Mckenna M Oliver; JR Soc Med 2002;95:511-513

Antonelli MA. Accuracy of second-year medical students' self-assessment of clinical skills Acad Med 1997;72: 563-5

Boud D. Enhancing Learning through Selfassessment. London: Kogan Page, 1995

Brown G, Bull J, Pendlebury M. Assessing Student Learning in Higher Education. London Routledge, 1997.

Sullivan K, Hall C. Introducing students to selfassessment. Assess Eval Higher Ed 1997;22: 289-303.

Brown S, Knight P. Assessing Learners in Higher Education. London: Kogan page, 1994.

Chur-Hansen A. The self-evaluation of medical communication skills. Higher Ed Res Devel 2001;20: 71-9.

Shunk DH. Goal and self-evaluation influences during children's cognitive skill learning. Am Ed Res J 1996;33: 359-82.

McDonald, B. \& Boud, D. (2003) The impact of self-assessment on achievement: the effects of self-assessment training on performance in external examinations. Assessment in Education 10(2), 209-220.

Epstain RM, Hundert EM. Defining \& assessing professional competence. JAMA 2002;287:226235

Winning T, Lekkas D \& Townsend G.. (2007). Developing Clinical Self Assessment Skills in First Year Dental Students From the REAP International Online Conference on Assessment Design for Learner Responsibility,29-31th May,2007

Donald A Curtis, Samuel L et al. Journal of Dental Education(American Dental Education association) 72(3).265-277 2008.

Race P, Page K. Assessment A Briefing on Self, Peer \& Group assessment. 'The Lecturer's Toolkit, $2^{\text {nd }}$ Edition, LSTN Generic Center assessment Series 2001.

Sargeant J, Mannin K, Vander C. Directed Self Assessment: Practice \& Feedback within a social Context.Journal Of Continuing Medical Education In The Health Professions, 28(1):4754,2008 .

Van Harlow 19996. 